\title{
Vertical Profile of Water and Sediment in Lake Oigon
}

\author{
Byambadulam Enkhee ${ }^{1}$, Buyan Chuluun ${ }^{1}$, Bayanmunkh Baatar ${ }^{2}$, Shurkhuu \\ Nyamdorj ${ }^{1}$, Sen-Lin Tang ${ }^{3}$, Bolormaa Oyuntsetseg ${ }^{1, *}$ \\ ${ }^{1}$ Department of Chemistry, School of Arts and Sciences, National University of Mongolia, Ulaanbaatar 14201, \\ Mongolia \\ ${ }^{2}$ Mongol-Us SEO, Ulaanbaatar 16051, Mongolia \\ ${ }^{3}$ Biodiversity Research Center, Academia Sinica, Taipei 11529, Taiwan \\ "Corresponding author. Email: bolormaa@ num.edu.mn
}

\begin{abstract}
Determining vertical variation of water quality parameters is contributed to a better understanding of the true nature of lakes. Lakes are classified into holomictic and meromictic lakes by their mixing mode; the former occurs physicochemical mixing between the surface and deep waters, while the latter layers of lake water occur unmixed for years, decades, or centuries. Lake Oigon is the only Meromictic Lake identified in Mongolia. Few Mongolian lakes have been studied in different seasons but not in the vertical directions. Therefore, we studied the vertical profile of water and sediment parameters in Lake Oigon for two years. Physico-chemical parameters in water were measured on-site, while sediment parameters were determined off-site. Salinity in lake water ranged from 21.3 to $65.9 \mathrm{~g} / \mathrm{L}$ which represented mesosaline to hypersaline. In oxic, sub-oxic, and anoxic zones, the physico-chemical parameters of Lake Oigon were varied a lot in longitudinal ways lake and seasonal variation observed as well. However, most parameters were stable in the anoxic zone, regardless of seasons, indicating that no water movement was at the bottom of the lake. Layered sediments with salt indicating hardly exchange with lake water at the anoxic zone. The statistical correlation and principal component analysis between the various physico-chemical parameters of lake water and lake sediment were computed. This study provides the basic information for future research on the characteristic of the vertical profile, impact on the ecosystem, and environmental assessment for Lake Oigon.
\end{abstract}

Keywords: Vertical profile, Water, Sediment, Physico-chemical parameters, Seasonal variation

\section{INTRODUCTION}

Meromictic lakes defined by Hutchinson (1957) are lakes in which some water remains partially or wholly unmixed with the main mass of water at the normal circulation periods. Meromictic lakes are interesting objects for research for physical stability of the water masses, clearly separated layer, relatively constant vertical stratification in bacterial populations, physicochemical parameters of water, and bottom sediment. Meromictic lake sediments stand for climate records, which range from a few hundred years to more than ten thousand years [1].

Most lakes are Holomictic lakes, which occur Physico-chemical mixing between the surface and deep water. Meromictic lakes are rare compared to holomictic lakes. Hall and Northcote (2012) listed 177 meromictic lakes on the Globe [2]. Usually, these lakes are permanently stratified by a chemical gradient that separates their dense underlying monimolimnion from the overlying less dense mixolimnion. In salt lakes, the bottom layer of water (monimolimnion) often does not circulate annually due to a strong density difference caused by the salinity gradient at the boundary of the mixolimnion and the monimolimnion. Since the monimolimnion is excluded from the gas exchange for several years, it very often becomes anoxic. The mixolimnion and the monimolimnion are quite different in terms of water properties. This type of change of the water properties often happens within a thin water layer, which is called halocline (salinity gradient), chemocline (chemical gradient), or pycnocline (density gradient) [3]. The depth of the Meromictic Lake is divided into oxic, suboxic, and anoxic zone $[4,5,6]$. Meromictic lakes have a mixed upper oxic mixolimnion, an interface chemocline, and a lower stagnant anoxic monimolimnion, which does not mix with either of the upper layers $[7,8,9]$. 
Their specific zones once having stratified and unique biogeochemical characteristics could generally provide the novel opportunities to compare microbial loops and biogeochemical processes among the distinct zones [10].

Determining the vertical variation of water quality parameters are contributing to a better understanding of the seasonal mixing and stratification patterns. Lake Oigon was currently the first identified meromictic lake in Mongolia [11]. Vertical profile and seasonal variations in the physico-chemical properties of the Lake Oigon water had not been studied. In this study, we investigated the physico-chemical parameters in the seasonal variations along with the vertical profile of water and sediment in Lake Oigon during the summer and winter of two years. The main aim of this study is to investigate the characteristic of the vertical profile, to collate data about the vertical profile of Lake Oigon, to describe the nature of the lake's stratification, and to explain the patterns of its seasonal variations.

\section{EXPERIMENTAL}

\subsection{Description of the Study Area}

Lake Oigon is located $1664 \mathrm{~m}$ above sea level in Tudevtei soum of Zavkhan province, the western part of Mongolia. It is an endorheic water body, and the surface area of the lake is $61.3 \mathrm{~km}^{2}$ with a maximum water depth of $8 \mathrm{~m}$. Most coasts are surrounded by high hills except the northwestern shore, which is plain. Lake Oigon has a potent and clear crystalline salt layer that regenerates spontaneously after excavation as a result of underground influxes of hypersaline water.

Lake water temperature is ranged $18.0-19.5^{\circ} \mathrm{C}$ at the surface and $16.0^{\circ} \mathrm{C}$ at depth from July to August. It is covered by thick ice with $1.0-1.2 \mathrm{~m}$ in November and May. Substrates tend to be sandy and often constitute true peat bogs.

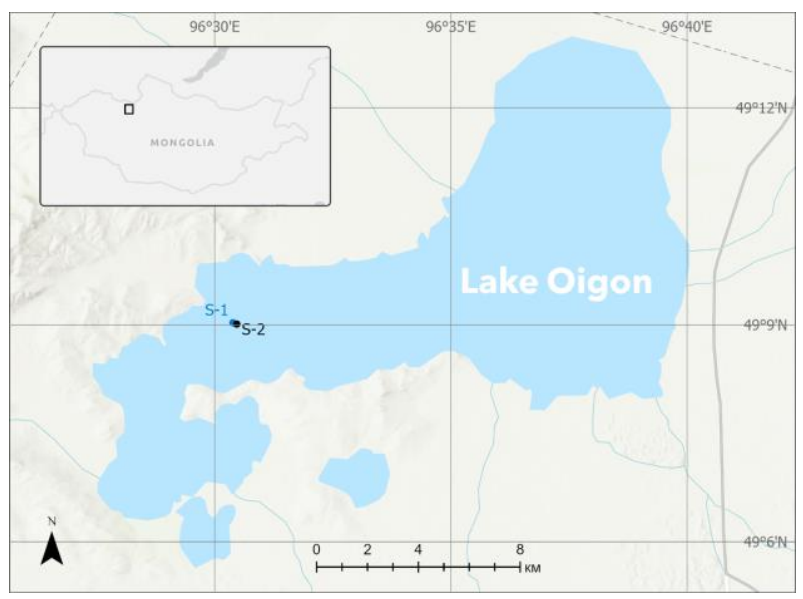

Figure 1. Map of the study area

The littoral zone of the lake is completely white due to precipitated salts of $\mathrm{NaCl}$ and $\mathrm{Na}_{2} \mathrm{SO}_{4}$. It has halophyte vegetation [12]. The map was showed sampling locations in the study area (Figure 1).

\subsection{Sampling Procedures}

Lake water and lake sediment samples were collected at the center point of lake on July 2018, February 2019, June 2019, and January 2020, respectively. Lake water was sampled at every meter of water depth using a depth water sampler. All bottles were thoroughly cleaned before sampling to prevent contamination. Lake sediment was sampled at every 10 centimeters of sediment depth using a depth sediment sampler. Sediment samples for physico-chemical parameters analysis were kept at $4{ }^{\circ} \mathrm{C}$ before arrival at the laboratory.

\subsection{Analysis}

The physico-chemical parameters in water were measured on-site, while sediment parameters were determined at the laboratory. The physico-chemical parameters including $\mathrm{pH}, \quad$ salinity, electrical conductivity (EC), dissolved oxygen (DO), and oxidation-reduction potential (ORP) were measured with the portable multiparameter (Model: HI 9828, Hanna Instruments, Woonsocket, Rhode Island, USA).

\section{RESULTS AND DISCUSSION}

Dissolved oxygen and $\mathrm{pH}$ affect directly or indirectly other limnological parameters such as transparency, viscosity, total dissolved solids, and conductivity [13], all of which constitute the very important physical and chemical parameters that form the basis for water resources management [14].

\subsection{Physico-chemical Analysis}

The vertical profiles of physico-chemical parameters of the lake were presented in Figure 2. Lake water $\mathrm{pH}$ represents one of the most important indicators for influencing the evolution of the aquatic ecosystem. In general, results showed that the Lake water was alkaline and had an average $\mathrm{pH}$ of 9.17 (range from 8.18 to 9.65) or slightly alkaline. As shown $\mathrm{pH}$ diagram, there was a tendency of seasonal variation which was increased the $\mathrm{pH}$ in summer and decreased the $\mathrm{pH}$ value in winter along with the depth (Figure 2a). Photosynthesis by aquatic plants during the daylight removes carbon dioxide $\left(\mathrm{CO}_{2}\right)$ from the medium hence $\mathrm{pH}$ would increase. At night, respiratory processes of aquatic organisms release $\mathrm{CO}_{2}$ into the medium, and $\mathrm{pH}$ declines [15]. Similarly, factors in which the lake's water temperature is warmer in summer than in winter and the night time in summer lower than in winter, etc created seasonal variations. The $\mathrm{pH}$ value of lake sediment was range from 8.45 to 8.88 or slightly 
alkaline (Figure 2d). Seasonal variation of $\mathrm{pH}$ (sediment) was inversely correlated with seasonal variation of $\mathrm{pH}$ (water).
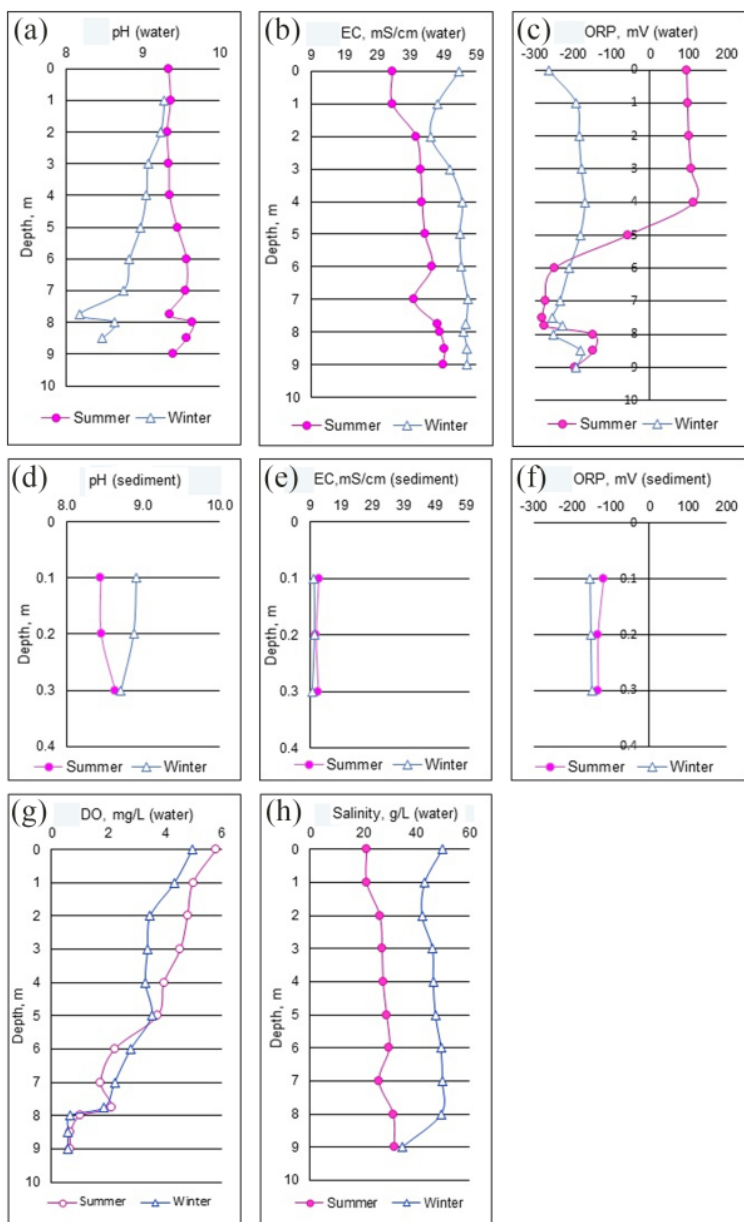

Figure 2. Vertical profiles of Physico-chemical parameters

Figure $2 b$ is shown the seasonal variation and pattern of the vertical distribution of the electric conductivity (EC) of Lake's water. Major ions like sodium, potassium, chloride, carbonate, sulfate, calcium, and magnesium contribute to the electric conductivity of Lake water. The range of EC in Lake was from 33.73 to $49.54 \mathrm{mS} / \mathrm{cm}$ in the summer and from 47.33 to $56.3 \mathrm{mS} / \mathrm{cm}$ in the winter, with an average value of $48.26 \mathrm{mS} / \mathrm{cm}$. During the winter, the lake is covered with 1.0-1.2 $\mathrm{m}$ thick ice, which reduced the amount of water in the lake and increased the EC. On the other hand, EC value in the summer is lower than EC value in the winter, due to increased lake water levels due to precipitation and river runoff, more dilution. EC value of sediment was range from 11.05 to $11.90 \mathrm{mS} / \mathrm{cm}$ in the summer and range from 9.75 to $10.35 \mathrm{mS} / \mathrm{cm}$ in the winter (Figure 2e). Seasonal variation of EC (sediment) was inversely correlated with seasonal variation of EC (water).
As can be seen from the Figure 2c, decreasing oxidation and reduction potential (ORP) along the water depth indicates a decrease of the oxidation process and an increase in the reduction process. The ORP varied between -280 and $+115 \mathrm{mV}$, depending on the season and sampling depth. Redox potentials of less than -100 $\mathrm{mV}$ indicate anaerobic environments, while values greater than $100 \mathrm{mV}$ indicate aerobic environments [16]. Thus, Lake Oigon was covered by $1.0-1.2 \mathrm{~m}$ thick ice in winter, creating an anaerobic environment along all depths of the lake. Whereas, an anaerobic environment is created below a depth of $6 \mathrm{~m}$ in the summer. The ORP of sediment was redox potentials of less than $-100 \mathrm{mV}$ (Figure 2f), indicated anaerobic environments regardless of the season.

Seasonal variation and pattern of the vertical distribution of the dissolved oxygen (DO) concentration of Lake's water is shown in Figure $2 \mathrm{~g}$. Three zones were identified from the DO graph: oxic, sub-oxic, and anoxic. A sharp drop of DO concentration was observed at a depth of below $5 \mathrm{~m}$. Thus we predicted there is the oxic zone at a depth range from the surface to $5 \mathrm{~m}$. DO concentrations were ranged from $3.30 \mathrm{mg} / \mathrm{L}$ to 5.80 $\mathrm{mg} / \mathrm{L}$ in the oxic zone. DO concentrations were recorded range from $0.67 \mathrm{mg} / \mathrm{L}$ to $2.79 \mathrm{mg} / \mathrm{L}$ at a depth range from $5 \mathrm{~m}$ to $8 \mathrm{~m}$, from $0.0 \mathrm{mg} / \mathrm{L}$ to $0.67 \mathrm{mg} / \mathrm{L}$ at depth range from $8.5 \mathrm{~m}$ to bottom. We predicted according to the Dissolved oxygen diagram, there is the oxic zone at a depth of 1-5 m, sub-oxic at depth of 5-8 $\mathrm{m}$, and anoxic zone at depth of 8.5-9 $\mathrm{m}$ in Lake Oigon. The seasonal variation was observed sharply trend in the oxic zone of Lake, DO concentration was decreased in winter. High concentration values of dissolved oxygen are recorded in summer while low concentration values are present during winter, as a result of the ice cover. The pattern of the vertical distribution of dissolved oxygen followed a similar trend as that of ORP except that a sharp drop in DO usually occurred at the $5 \mathrm{~m}$ depth.

Seasonal variation and pattern of the vertical distribution of the salinity (Sal) of Lake's water are shown in Figure $2 \mathrm{~h}$. The salinity of lake water ranges from 21.3 to $31.7 \mathrm{~g} / \mathrm{L}$ in summer and from 34.74 to 49.9 in the winter, had an average salinity of $37.29 \mathrm{~g} / \mathrm{L}$. Lake Oigon salinity was from mesosaline to hypersaline according to based on Hammer categories [17]. Lake Oigon average salinity value was much higher when compared with the salinity values obtained from Lake Shira, Russia (ranges from $14 \mathrm{~g} / \mathrm{L}$ to $15 \mathrm{~g} / \mathrm{L}$ in the epilimnion and about $18 \mathrm{~g} / \mathrm{L}$ in monimolimnion, based on data from 2007-2009) [18] as well as these from Lake Shunet, Russia (ranges from 10 to $25 \mathrm{~g} / \mathrm{L}$ ) [19]. The seasonal variation was observed, salinity concentration was increased in winter. Salinity in the summer is lower than Salinity in the winter, due to increased lake water levels due to precipitation and river runoff, more dilution. 
The values of all physico-chemical parameters (except $\mathrm{pH}$ ) were almost constant at the bottom of the lake, regardless of the seasonal variation, indicating that water movement is constant.

\subsection{Principal Component Analysis (PCA)}

PCA is a common statistical method used to interpret environmental data. We used PCA analysis to observe the dissimilarity and statistical correlation among the inter-correlated variables of physicochemical parameters. In the PCA, the direction and length of the arrows show the degree of correlation between fractions and the principal components.

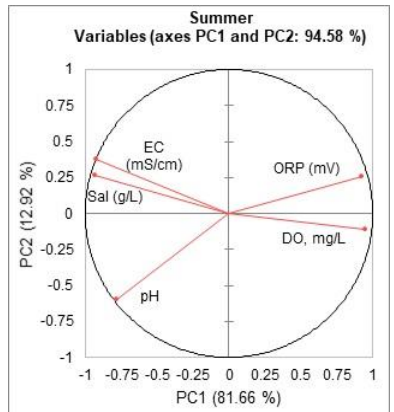

PC1 (81.66 \%)

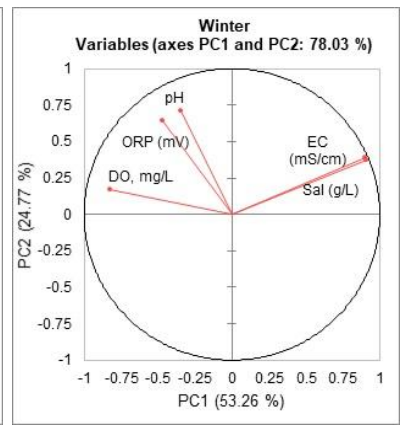

Figure 3. PCA plot of physico-chemical parameters

Figure 3 shows PCA results of physico-chemical parameters. Two significant components of Total concentration account for $94.58 \%$ of the total variance. PC1 accounts for $81.66 \%$ of total variance (eigenvalue=4.083). DO and ORP have higher positive loadings, showing similar patterns among sampling points at depth. PC1 had strong negative loading of $\mathrm{pH}$. On the other hand, $\mathrm{PC} 2$ accounts for 12.92 of variance (eigenvalue $=0.646$ ). PC2 had strong positive loading of EC, and Salinity in summer. EC and Sal showed that there was high dissimilarity and not correlated with the depth of lake water in summer. EC and sal were dissimilar in the summer, maybe related to the increased lake water levels due to precipitation and river runoff, more dilution.

Two significant components of Total concentration account for $78.03 \%$ of the total variance. PC1 accounts for $53.26 \%$ of total variance (eigenvalue=2.663). Sal and EC have higher positive loadings, showing similar patterns among sampling points at depth in winter. PC2 accounts for 24.77 of variance (eigenvalue=1.239). PC2 had strong positive loading of $\mathrm{pH}, \mathrm{DO}$ and ORP in the winter. The $\mathrm{pH}, \mathrm{DO}$, and ORP showed that there was high dissimilarity and not correlated from the depth of lake water in winter. ORP had a weak association $(<0.7)$ with the two components. The $\mathrm{pH}$, DO, and ORP were dissimilar in winter, probably related to being covered by thick ice. ORP was a weak association with the two components, related to creating an anaerobic environment due to the thick ice cover.

\section{CONCLUSION}

We studied seasonal variations of the physicochemical parameters along with the depth of Lake Oigon, Mongolia obtained in the process of routine monitoring from 2018 to 2020. Physico-chemical parameters of the water of Lake Oigon were different depending on the oxic, sub-oxic, and anoxic zones. The salinity in the bottom of the vertical profile hardly changed during the seasons indicating the absence of full circulation of water in Lake Oigon. Values of $\mathrm{pH}$, ORP, and DO were increased in summer. Inversely, values of EC and salinity were decreased in summer. Seasonal variation of $\mathrm{pH}$ (sediment) and EC (sediment) was inversely correlated with seasonal variation of $\mathrm{pH}$ (water) and EC (water). EC and Salinity in the summer, and $\mathrm{pH}, \mathrm{DO}$, and ORP in winter indicated the dissimilar among physico-chemical parameters by PCA analysis. By studying seasonal variation physico-chemical parameters in the water of meromictic Lake Oigon, researchers were able to provide the basic information for further investigations on the describe the nature of the lake's stratification and to explain the patterns of its seasonal variation of Lake Oigon.

\section{ACKNOWLEDGMENTS}

We thank our project team at the National University of Mongolia for their assistance in providing samples and hydro-parameter data. This study was supported by the thematic project funding of Mongolian-Taiwan Joint Project (TWN_17/002) from the National Sciences Council of Taiwan and the Ministry of Education, Culture and Science of Mongolia.

We are grateful to B.Ganchimeg and colleagues of the staff governor of Tudevtei soum, Zavkhan province for assisting samples collection.

\section{REFERENCES}

[1] Zadereev E.S., Gulati R.D., Camacho A., (2017) Biological and ecological features, trophic structure and energy flow in meromictic lakes. In Ecology of meromictic lakes (61-86). Springer, Cham. DOI: 10.1007/978-3-319-49143-1_4

[2] Egor S., Zadereev B.B., (2017) Meromictic Lakes, Their Terminology and Geographic Distribution. In E.S. Ramesh D. Gulati, Ecology of Meromictic Lakes (1-14). Springer. DOI: 10.1007/978-3-31949143-1_1

[3] Bertram B., Martin S., (2008) Stratification of lakes. Reviews of Geophysics. 46, DOI: 10.1029/2006RG000210

[4] Andrei A.Ş., Robeson M.S., Baricz A., Coman C., Muntean V., Ionescu A., Banciu H.L., (2015) 
Contrasting taxonomic stratification of microbial communities in two hypersaline meromictic lakes. The ISME Journal, Vol. 9(12), 2642-2656. DOI: 10.1038/ismej.2015.60

[5] Balistrieri L.S., Murray J.W., Paul B., (1994) The geochemical cycling of trace elements in a biogenic meromictic lake. Geochimica et Cosmochimica Acta, Vol. 58(19), 3993-4008. DOI: 10.1016/0016-7037(94)90262-3

[6] Bosshard P.P., Stettler R., Bachofen R., (2000) Seasonal and spatial community dynamics in the meromictic Lake Cadagno. Archives of microbiology, Vol. 174(3), 168-174. DOI: $10.1007 / \mathrm{s} 002030000191$

[7] Bowman J.P., McCammon S.A., Rea S.M., McMeekin T.A., (2000) The microbial composition of three limnologically disparate hypersaline Antarctic lakes. FEMS Microbiology Letters, Vol. 183(1), 81-88. DOI: 10.1111/j.15746968.2000.tb08937.x

[8] Boehrer B., von Rohden C., Schultze M., (2017) Physical features of meromictic lakes: stratification and circulation. In Ecology of meromictic lakes (pp. 15-34). Springer, Cham. DOI: 10.1007/978-3319-49143-1_2

[9] Schultze M., Boehrer B., Wendt-Potthoff K., Katsev S., Brown E. T., (2017) Chemical setting and biogeochemical reactions in Meromictic Lakes. In Ecology of Meromictic lakes (pp. 35-59). Springer, Cham. DOI: 10.1007/978-3-319-49143$1 \_3$

[10] Comeau A.M., Harding T., Galand P.E., Vincent W. F., Lovejoy C., (2012) Vertical distribution of microbial communities in a perennially stratified Arctic lake with saline, anoxic bottom waters. Scientific reports, Vol. 2(1), 1-10. DOI: $10.1038 /$ srep00604

[11] Baatar B., Chiang P.W., Rogozin D.Y., Wu Y.T., Tseng C.H., Yang C.Y., Tang S.L., (2016) Bacterial communities of three saline meromictic lakes in Central Asia. Plos one, Vol. 11(3), e0150847. DOI: 10.1371/journal.pone.0150847

[12] Tserensodnom Z., (2000). Catalogue of the Mongolian Lakes. Ulaanbaatar: Shuvuun saaral.

[13] Whitney J., (1942) Diurnal fluctuations of oxygen and $\mathrm{pH}$ in two small ponds and a stream. Journal of Experimental Biology, Vol. 19(1), 92-99.

[14] Araoye P.A., (2009) The seasonal variation of $\mathrm{pH}$ and dissolved oxygen $\left(\mathrm{DO}_{2}\right)$ concentration in Asa lake Ilorin, Nigeria. International Journal of Physical Sciences, 271-274.
[15] King D.L., (1970). The role of carbon in eutrophication. Water Polution Control Federation, 2035-2051. DOI: $10.2307 / 25036835$

[16] Suthersan S.S., (2001) Natural and enhanced remediation systems. Washington: Lewis

[17] Hammer U., (1986) Saline lake ecosystems of the world. Kluwer academic.

[18] Rogozin D.Y., Genova S.N., Gulati R.D., Degermendzhy A.G., (2010) Some generalizations based on stratification and vertical mixing in meromictic Lake Shira, Russia, in the period 2002 2009. Aquatic ecology, Vol. 44(3), 485-496. DOI: $10.1007 / \mathrm{s} 10452-010-9328-6$

[19] Rogozin D.Y., Zykov V.V., Degermendzhi A.G., (2012) Ecology of purple sulfur bacteria in the highly stratified meromictic Lake Shunet (Siberia, Khakassia) in 2002-2009. Microbiology, Vol. 81(6), 727-735. DOI: $10.1134 / \mathrm{S} 0026261712060148$ 